\title{
UNCTAD and the Commodity Problems of Developing Countries
}

\section{by Alf Maizels}

1. Nature of the commodity problem

It is well known that the great majority of developing countries depend on primary commodities for the bulk of their foreign exchange earnings - indeed for their very livelihood and economic development and that relatively few developing countries are important exporters of manufactured goods. This is very largely a transitional phase as more and more developing countries succeed in industrialising their economies, and in shifting away from the former colonial-type dependence on the metropolitan countries to supply their requirements of manufactures and to serve as markets for their primary produce. For many, if not most, developing countries this transitional phase could extend into the next century; meanwhile, primary commodities will remain a crucial element in their total foreign exchange earnings.

The transitional problems of industrialisation are seriously accentuated by the vicissitudes of the world market for many primary commodities, since financing the external component of industrialisation programmes must fall very largely on commodity export earnings. Primary commodity markets are, generally speaking, distinguished from the markets for manufactures in two ways. First, most primary commodities are subject to substantially greater short-term price instability than are manufactures. Indeed, it is exceptional to find manufactures declining in price in this age of inflation in developed countries; 'instability' is rather related to an uneven rate of increase in prices. For many primary commodities, by contrast, we continue to witness substantial price fluctuations, in both directions. Sharp price declines (due, for example, to a heavy crop) can even endanger the political stability of particular countries (Ghana being an obvious example).

*A1f Maizels is Deputy Director of the Commodities Division of UNCTAD. The opinions expressed in this paper are not necessarily those of the Secretariat. 
Second, over the longer term, the prices of manufactures tend to rise (at least, this has been the experience since the end of World War II), as the rise in productivity is more than offset by increases in profits and/or costs. Primary product prices, however, have moved in a cycle, rising generally to a peak in the mid-1950's, falling to a low point in the early $1960^{\prime} \mathrm{s}$ and then staging a recovery until they are now roughly back to the mid-1950 leve1. The experience of individual developing countries in this respect has varied widely. Even in the recent upward phase of the cycle - over the past decade - a number of developing countries experienced declines in their export prices.

Whether or not this price cycle is superimposed on any definite underlying trend is a moot point, often hotly disputed. However, what seems not in doubt is that for a wide range of agricultural products, the atomistic character of production, and the 1 ack of financial reserves of individual producers in developing countries, results in a weak bargaining position for such producers in the world market. This is accentuated where the international distributive mechanism is largely in the control of oligopolistic enterprises of developed countries. This weak market position of developing countries is, in a sense, a reflection of their underdevelopment insofar as they find it difficult to shift the structure of output away from excessive dependence on the export of 'problem' commodities.

Though the particular problems of individual commodity markets vary widely, it is convenient for purposes of analys is and consideration of policy to group commodities according to the nature of their main problems. Four principal groups can be distinguished, apart from petroleum, which constitutes a special case (see Table 1 ). The first group comprises virtually the entire range of agricu1tural raw materials, which have been facing a growing threat to their traditional markets from alternative synthetic materials. Over the past decade, the effects of competition from synthetics, allied to continued growth in production of agricultural raw materials, has resulted in a significant downward price trend, which has 1argely offset the benefit of the expansion in the volume of developing countries' exports. 
Table 1. Rates of change in unit value, volume and value of major commodity groups exported from developing countries, 1959-61 to $1967-69$

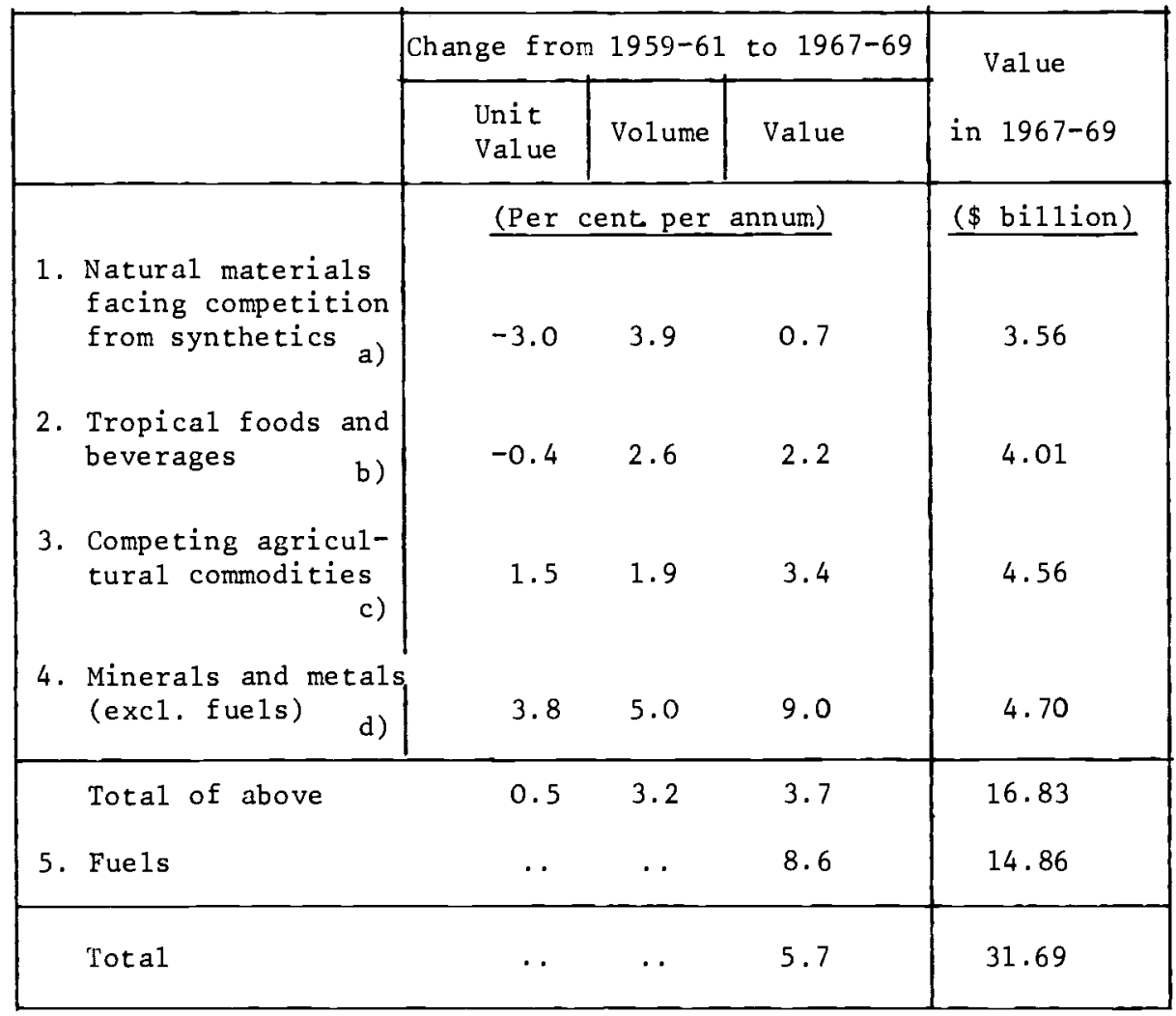

Source: Pricing policy, including international price stabilisation measures and mechanisms (TD/127), UNCTAD, Geneva, February 1972 .

a) Cotton, wool, natural rutber, tropical timber, jute and hard fibres.

b) Coffee, cocoa, tea, bananas and pepper.

c) Sugar, vegetable oilseeds and oils, cereals, beef and veal, citrus fruits and tobacco.

d) Iron ore, copper, lead, zinc, bauxite (incl. alumina and aluminium), manganese ore, tungsten concentrates and phosphate rock. 
A second group, consisting of tropical foods and beverages, has suffered on average a marginal decline in prices over the decade (upward price movements for some tropical products - e.g. cocoa and bananas - being more than offset by downward movements for others - e.g. tea and coffee). The underlying problem here is that for most tropical foods demand in high-income countries tends to be income-inelastic, whereas supply tends to continue to expand with the entry of new producing areas and the secular improvement in productivity.

For both these commodity groups, the expansion in export volume from developing countries has necessarily involved the use of additional resources, part of the expansion reflecting - as a1ready indicated - improvements in productivity. To the extent that these productivity improvements have been offset by price declines, however, their resultant benefits have accrued to the importing (predominant 1 y developed) countries.

A third major group consists of agricultural products exported by developing countries which compete directly with the protected production (essentially of temperate-zone foodstuffs) of developed countries. The basic problem is how to achieve a progressive improvement in market access without, at the same time, reducing the living standards of the farm community in developed countries. The fourth group distinguished in Table 1 - minerals and metals other than fuels - experienced considerably more favourable market trends over the past decade than any of the groups of agricultural products. Overall, mineral prices as well as volume of trade have risen significantly, though there are some important minerals (iron ore and manganese ore) which have suffered from declining price trends.

\section{The role of UNCTAD in international commodity policy}

The problems outlined above are not new ones. Nor are they necessarily inherent in the nature of commodity production and trade. But international remedial action until the establishment of UNCTAD in 1964 tended to ignore many aspects of the commodity problem, being generally based on the assumption - enshrined in the Havana Charter - that the free market $c$ an be relied on to secure an optimal international division of labour, apart from certain exceptional and carefully defined cases for which international control agreements could be envisaged. The climate of international discussion and action was however changed abruptly by the creation of UNCTAD, and the placing in the forefront of international commodity policy the need for a comprehensive strategy to assist the economic development of the developing countries. 
The Final Act of the first UNCTAD in 1964 set out the new principles of such a strategy, though most of the industrialised countries entered reservations at critical points. In recent years, and particularly since the second session of UNCTAD in 1968, the organisation's work in the commodities field has focused on more practical activities, designed to tackle the problems of particular commodities. Taking the first group of commodities in Table 1 , the problems of natural materials facing competition from synthetics and other substitutes were assigned in 1965 to a Permanent Group on Synthetics and Substitutes, a subsidiary body of UNCTAD's Committee on Commodities. The Permanent Group has devoted priority attention in the past few years to the need for a considerable expansion in the research and development ( $R$. and D.) effort devoted to improving the competitive position of the principal natural products facing competition from synthetics. It has initiated a survey of current $R$. and $D$. efforts for each of these natural products as a basis for determining the main gaps to be filled. These surveys some of which are still in progress - are being undertaken by the various specialised intergovernmental commodity bodies (such as the International Rubber Study Group, the International Cotton Advisory Committee, and FAO's Consultative Committees on Jute and on Hard Fibres) and, for commodities for which such bodies do not exist, by the UNCTAD secretariat. The results of these surveys so far have clearly indicated the enormous $1 \mathrm{ag}$ in $R$. and D. of most of the natural materials industries, compared with the investment in $R$. and D. by the synthetics industries.

As a result of the work of the Permanent Group, and of the specialised commodity bodies, a series of we11-conceived $R$. and $D$. programmes on a global scale could emerge. They will, of course, require new finance, and here the international financial institutions, supported by UNDP, could have a major role to play. There seems 1 ittle doubt that such $R$. and $D$. programmes - designed to improve productivity, to develop new end-uses and to improve quality and technical characteristics - would constitute an essential element in a viable long-term strategy to improve the competitive position of these natural materials.

The Permanent Group has also considered in detail the problems of individual natural materials, particularly those of natural rubber. A comprehensive report by the UNCTAD secretariat on the world rubber industry, including proposals for international action, is now under consideration both in UNCTAD and in the International Rubber Study Group. For the lauric acid oils (coconut oil and palm kernel oil), a major element in the deterioration of their competitive position vis-ä-vis synthetics has been the large seasonal variation in supply and the consequent substantial short-term price 
fluctuations. The UNCTAD secretariat has developed an econometric model of the world market for lauric oils, on the basis of which alternative supply stabilisation schemes can be simulated, and close co-operation in developing a viable scheme of this kind is maintained both with FAO and with the Asian Coconut Community.

Turning now to the second group of commodities, the tropical foods and beverages, the major avenue of international action consists of market regulation (usually by means of export quotas and/ or international buffer stocks) through international comodity agreements. Formal agreements of this kind are binding on signatory governments, and have the status of international treaties. Negotiations to conclude a new agreement, or to renew an existing one, are convened by UNCTAD, by virtue of a General Assembly resolution. The negotiation of the two new agreements since the creation of UNCTAD - those for sugar in 1968 and for cocoa in 1972 - has proved how difficult and time-consuming such negotiations are. The effort to extend the coverage of commodity agreements to other tropical products is likely to continue to be a major preoccupation of UNCTAD in the field of commodity trade. Over the past two years, for example, the UNCTAD and FAO secretariats have been working jointly to evolve basic principles for a long-term agreement on tea

For this group of commodities, an agreement which regulates the rate of expansion in total world exports can, in principle, be used to raise prices above the levels which would otherwise obtain, and so benefit the export earnings of developing producing countries. This is because demand is inelastic for most tropical foods (particularly for coffee, cocoa and tea), and there are no important direct substitutes in consumption. Consequently, a given reduction in supply will result in a more than proportionate increase in price, at least in the short and medium term. The main problems are to evolve an agreement which is sufficiently flexible to allow for changing shares of the world market for the various producing countries, with changes in relative costs and productivity; to cover the preponderant share of world exports and imports; and to secure the co-operation of the principal importing countries in operating the agreement.

Many of the commodities in this group (and particularly coffee) are subject to revenue duties in consuming countries. The elimination of these duties, often called for by the exporting countries concerned, would not, however, result in any significant increase in sales in developed countries because of the generally low priceelasticity of demand. For this reason, an alternative approach has been advocated in recent years, both in UNCTAD bodies and outside, namely, that developed countries which impose such duties should 
remit some proportion of the proceeds to the developing expor ting countries concerned.

Another possible line of action to achieve a more remunerative level of prices for developing countries exporting tropical commodities would be a compensatory financial arrangement under which all, or part, of the difference between actual prices and an agreed reference price would be made up to the exporting countries. Compensatory payments (which would need to be related to agreed quantities in order to avoid an open-ended commitment by the developed importing countries) could also be linked, where necessary, to diversification programmes in the developing countries. 1 So far, however, the developed countries have not been willing to give practical consideration either to a transfer of a proportion of the proceeds of revenue duties, or to a possible compensatory financing arrangement for individual tropical commodities.

The third group to be considered consists of comnodities exported by developing countries which compete with domestic, protected, production in developed countries. Exports of these commodities are substantially affected by the operation of a wide range of protectionist measures in developed countries, where an increasing trend towards self-sufficiency in temperate-zone foodstuffs reflects the desire of governments to maintain the real incomes of their farm communities at levels corresponding to those of the urban pooulation. The ecomomic costs of such protectionist policies have been heavy - not only for lower-cost producers in developing countries, but also for the developed countries themselves in terms of surplus production, increased taxation and high retail prices. Moreover, the beneficiaries of higher farm prices have been mainly the larger, more efficient, farms, while the poorer farmers' incomes have, by and large, failed to improve.

The present price and income supports operating in developed countries thus result in a major distortion of the international division of labour. The adoption by Britain of the Common Agricultural Policy of the EEC is likely to make this distortion even greater. There has, however, been a growing awareness in recent years of the potential gains to be derived from a more rational allocation of the world's resources in the production of this important group of conmodities.

1 For a more detailed discussion of the revenue duty and compensatory financing issues, see TD/127, op. cit. 
In this connection, UNCTAD's Committee on Commodities has discussed the possibility of some form of 'market sharing' arrangement, whereby developed countries would undertake a commitment to ensure that an increasing share of their domestic requirements of particular commodities is met by imports from developing countries. Where imports are already regulated by quotas (as under the U.S. Sugar Act or the Commonweal th Sugar Agreement), this objective can be met by changing the quotas under existing 1 aw. But broadly similar effects could also be envisaged for other commodities in this group, such as rice, cotton, tobacco and meat, as a result of appropriate changes in current domestic price and income support policies of developed countries.

Such market-sharing arrangements would clearly have to be negotiated on a commodity-by-commodity basis for each of the developed countries. This raises the question of the appropriate institutional framework within which such negotiations can best take place.

This whole problem of barriers to market access for the commodity exports of developing countries was perhaps the most important aspect of the commodity problem considered by UNCTAD III in Santiago in the Spring of 1972. As is well known, the Conference failed to reach agreement on practical measures to improve access to markets, an area of vital importance to a large number of developing countries. However, the possibility of some concerted international action by UNCTAD on this matter has been left open by the Conference resolution that the forthcoming session of the Committee on Commodities (in 1973) should be a special session to organise intergovernmental consultations on agreed commodities, and to set up ad hoc consultative groups as appropriate in order to achieve significant improvements in market access and pricing policy early in the 1970 's. Whether, and to what extent, practical action will result from this new move remains to be seen - the most important ingredient for success, as previously, is the political will of the governments, particularly of developed countries, to achieve concrete results.

A separate resolution of UNCTAD III requested the UNCTAD secretariat to assist developing countries participating in the multi-lateral trade negotiations envisaged to commence in GATT in the course of 1973. The principles on which the GATT negotiations will proceed in the field of agricultural commodities have still not been agreed. Nor is it yet clear how these negotiations will be related to any international action under the aegis of the UNCTAD Committee on Commodities, though clearly the two operations should be mutually supporting, and not duplicative. Nonetheless, this new responsibility of UNCTAD specifically to assist the developing 
countries in the context of GATT, taken together with UNCTAD's own efforts in this area, imply that UNCTAD could play an important role in any general move towards freer trade in primary commodities.

As regards the fourth group of commodities - minerals and metals other than fuels - UNCTAD's work has focused on those minerals with unfavourable trends in market prices and in the export earnings of developing producing countries; and on the prospective production of certain minerals from the sea-bed outside the limits of national jurisdiction. Ad hoc intergovernmental consultations have been held in the past two years to consider the special problems of iron ore, manganese ore and phosphates, while a standing UNCTAD Committee on Tungsten considers the specific problems of that metal. The possibility of production of certain minerals (particularly manganese, cobalt and nickel) from the sea-bed in the next five to ten years, could well have substantial adverse economic effects on existing producers of these minerals, particularly those in deve1oping countries. The UNCTAD secretariat is studying the probable magnitude of this new problem, with a view to proposing measures to safeguard the interests of developing countries.

General issues

The above, necessarily brief, review of UNCTAD's work in the field of commodity trade was related to the specific problems of each of the main group of commodities. In addition, there are a number of general problems to be considered, of which the most important relate to the marketing systems operating for the commodity exports of developing countries, and the efforts of these countries to diversify their economies.

There is great variety in the marketing and distribution systems in operation for the main primary commodities. For some agricultural crops, such as tea and tobacco, for example, most of the production is sold at auctions. For others, such as bananas, the crop is produced and marketed predominantly by vertically-integrated firms of developed countries. For many minerals, an important development in recent years has been the growth of sales on longterm contracts (Japanese purchases of iron ore being a notable example), while transfers from mines in developing countries to parent firms in developed countries are also of major importance. The importance of terminal markets also varies greatly from one commodity market to another.

Most of the present marketing arrangements were developed during the colonial era, though there have been important modifica- 
tions in more recent years. Nonetheless, it is probably true to say that the existing distributive systems were designed to provide the metropolitan countries with ample supplies of food and industrial materials at the lowest possible cost. They are not necessarily the optimal distributive systems from the viewpoint of assisting the economic development of the developing countries.

The need for studies in depth of the marketing and distribution systems for the main commodity exports of developing countries so as to identify areas of substantial inefficiency, or of substantial excess profits, has been considered both by UNCTAD's Committee on Commodities and, more recently, by UNCTAD III, which decided - by majority vote - to authorise a series of comprehensive studies on these lines. Though detailed studies will inevitably be difficult to carry out, particularly where an important proportion of world trade is marketed by large corporations not willing to reveal. business details, it is to be hoped that they will serve as a basis for consideration of possible improvements in the present international distributive arrangements for primary commodities for the benefit of the developing countries concerned.

Even if international action on the various lines discussed above is taken successfully, there will still be an urgent need for many developing countries to diversify their comodity production. Such diversification is particularly important for developing countries which are heavily dependent on 'problem' commodities for the bulk of their foreign exchange earnings. In this context, 'problem' commodities can be broadly defined as commodities in actual or potential surplus on the world market, or facing significant competition from synthetics. A number of developing countries formerly in this category have succeeded in shifting resources, at least to some extent, into the production of other commodities and manufactures, with more dynamic demand prospects. However, many small, poor, developing countries have found it very difficult to make any significant shifts in resource allocation, partly because thej.r low or stagnant level of export earnings precludes effective financing of the diversification required.

The need for practical action by the international community to assist the diversification of the economies of developing countries caught in a 'low income trap' as a result of an unfavourable commodity structure of exports has been a major concern of the UNCTAD Committee on Commodities in recent years. Though at UNCTAD III no agreement was reached on the principles of further action, the question of more intensive and purposeful international assistance in this field remains on the agenda of the relevant UNCTAD intergovernmental bodies. 


\section{The future outlook}

Since its creation in 1964 , UNCTAD has striven to achieve a consensus between developing and developed countries (both market economy and socialist) on a set of coherent and effective policy measures to deal with the urgent commodity market problems of developing countries. The consensus that has so far emerged - and which is manifested in the various commodity policies discussed above has been embodied in the International Development Strategy for the second U.N. Development Decade, which was adopted by the General Assembly at its 25 th session.

UNCTAD has thus provided not only a forum for the discussion of developing countries' commodity trade problems, but has also played a major role in the evolution of international policies in this field. Indeed, the pressures of the developing countries for the adoption of new policies by the international community to accelerate their economic development is reflected not only in the activities of UNCTAD; they have also had a profound impact on the orientation of the work of other international agencies concerned with economic development. In tackling the problems of individual primary commodities, UNCTAD co-operates closely at the secretariat leve 1 with FAO, which has special competence in regard to production and trade problems of agricultural commodities, and with the various autonomous intergovernmental commodity bodies, such as those for rubber, cotton, sugar, coffee and wheat. When appropriate, UNCTAD's Committee on Commodities acts as a focal point of co-ordination of the commodity policies of all the international bodies concerned with the trade problems of developing countries.

Nonetheless, there are still some major gaps in the policy consensus as it has so far emerged. Moreover, it would be foolish not to recognise that there is often a wide discrepancy between good intentions, or agreed resolutions in general terms, on the one hand, and practical action by governments, on the other. Some observers have argued that this reflects the generally low priority given by governments of developed countries to the trade problems confronting developing countries, and that this explains the 'lack of political will' about which much is heard at international meetings.

In the commodity field, a much higher priority would imply that the governments of developed countries concerned with trade in 'problem' commodities should approach the possibility of negotiating international agreements not solely from the viewpoint of their own trading interests, but rather as part of a wider strategy of economic assistance for the developing countries. It implies also the need to inject a greater sense of urgency into international con- 
sideration of commodity problems, as well as a greater willingness to seek solutions in non-traditional approaches. So $f a r$, international policy-making has focused very largely on meeting the problems of individual commodities. As indicated earlier, this strategy is complex and time-consuming. It could now be supplemented by a broader multi-commodity approach, including a programme of substantial improvement in market access for temperate-zone agricultural products, and market stabilisation arrangements for all those commodities still suffering from excessive short-term fluctuations. Indeed, without such new initiatives, and higher priority, it is difficult to see how the objectives of the International Development Strategy for the $1970^{\prime} s$ in the field of commodity exports of developing countries can successfully be achieved. 